Journal

of Geography,

Politics and Society

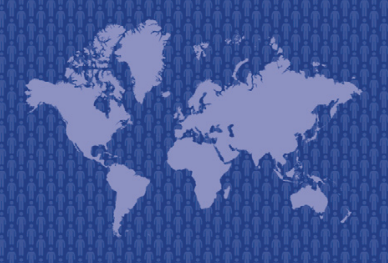

$9(3) / 2019$

\section{Journal of Geography, Politics and Society}

$2019,9(3), 14-22$

https://doi.org/10.26881/jpgs.2019.3.03

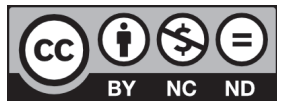

\title{
CHANGES OF TOURISM IN CROATIA IN THE POST-SOCIALIST PERIOD
}

\author{
Tomasz Wiskulski
}

Department of Tourism and Recreation Management, Faculty of Tourism and Recreation, Gdansk University of Physical Education and Sport, Górskiego 1, 80-336 Gdańsk, Poland, ORCID: 0000-0001-7802-721X

e-mail: tomasz.wiskulski@awf.gda.pl

\section{Citation}

Wiskulski T., 2019, Changes of tourism in Croatia in the post-socialist period, Journal of Geography, Politics and Society, 9(3), 14-22.

\section{Abstract}

21 years of transformation in the tourist function in the territory of Croatia has been summarized in the article. This area has come a long way from the region that was an integral part of Yugoslavia, through the area of warfare related to the civil war to one of the fastest growing tourist destinations in the world. The number of tourists has more than tripled, with an increase from $57 \%$ to $1830 \%$ in individual counties of Croatia during the analyzed period. At the same time, there was a disproportionately low increase in capacity of accommodation base across the country at the level of $76 \%$. This increase took values from $20 \%$ to $350 \%$ in extreme districts.

\section{Key words}

Croatia, Perkal Synthetic Indicator, Rectangular Coordinate System, tourism.

\section{Introduction}

Presenting the directions of changes in size and use of accommodation facilities in the tourist regions of Croatia in 1997 and 2017 was the purpose of this paper. A significant impact on tourist traffic and on development of the tourist function has quality and spatial diversity of the accommodation facilities (Pavia, Floricic, 2017; Rettinger, 2010; Salo et al., 2014; Scholz, 2016). The presentation of spatial and temporal variability in the size of indicators related to the tourist function has a crucial meaning in the assessment of tourist carrying capacity and tourist absorption (Matos Marquez, Perez Colmenares, 2019; Wang et al., 2019). Warfare led to a decrease in potential tourist interest in Croatia as a tourist destination. However, the free market reforms, the reconstruction of the country and the increase in tourist potential had a positive impact on the restoration of trust among visitors.

Croatia joined the EU in July 1993. It directly influenced the tourist services market. There has been 
a significant increase in the number of tourists, especially from EU countries, and the development of accommodation facilities. It is not without significance for the volume of tourist traffic was the visa requirement from April 1st, 2013 for citizens of countries such as Russia, Ukraine and Turkey. However, these changes didn't affect the average length of stay of tourists in Croatia.

\section{Data and methods}

Volume of tourist flows, accommodation base and its capacity at the level of County were used in the study (Statistical ..., 1997, 2017). In addition, data of surface area and population of County were used (Census ..., 2013). Statistical data describing tourist traffic and elements of tourism development at the level of NUTS 3 were used in paper. Data for 1997 and 2017 were used. On the one hand by their availability (data from 2017) and on the other by changes in the administrative division of Croatia (1997) was caused this selection. The change of the Knin region from Zadar-Knin County to Šibenik-Knin County (Narodne Novine, 10/1997) was decisive for the temporal scope of the study.

Tourism Density Index (Vojnovic, 2018), Schneider's Rate (Gogonea et al., 2017; Hacia, 2014), Tourist Accommodation Density Index (Markovic et al., 2017; Simancas Cruz, Penarrubia Zaragoza, 2019), BaretjeDefert's Index (Podhorecka, Dudek, 2019), Average Length of Stay (Duro, 2018), Accommodation Development Index (Wiweka, Arcana, 2016) and Charvát Index (Przybyla, Kulczyk-Dynowska, 2017; Stefko et al., 2018) were used in this paper. Presenting the structure of each of them is pointless because they are commonly used indicators in the description of tourist traffic and tourism development and their construction has been repeatedly described in the literature (Wiskulski, 2019).

To delimitate tourist regions on the territory of Croatia a numerous statistical methods were used. Use of them were considered complementary. The method of Rectangular Coordinate System is a method based on the variability of two features based on the one-class classification of continuous variables (Runge, 2006). The intensity ranges of a given feature should be determined in the adopted situation. Analyzed objects according to the measured feature, e.g. into two groups, are divided. Objects with a feature intensity below the accepted threshold are included in the first of them. Objects with a feature intensity above the accepted threshold are classified and we treat them as objects having established property are included in the second group. In the paper, in reference to the one-way classification, the values of the analyzed indicators were divided based on the customary (arbitrary) criteria.

To verify the results of the data analysis obtained by using the method of Rectangular Coordinate System, six partial indicators were analyzed using Perkal Synthetic Indicator. Refer to the actual values of the features were the main assumption of this method. Their quantities are given in various measuring units. Standardize them before making any further calculations was necessary.

\section{Results and discussion}

Tourism as a social and economic phenomenon is one of the factor determining implementation of tourism function in tourist region (Markovic et al., 2017; Muler Gonzalez et al., 2018). It can testify to the tourist attractiveness of the region as a social element. According to the adopted definition, indicators describing tourism and tourism development are included in basic elements that make up the tourist function. Indicators describing tourist traffic are: Tourism Density Index and Schneider's Rate. And group of indicators describing tourist development includes such indicators as: Baretje-Defert's Index and Tourist Accommodation Density Index. In order to demonstrate changes in the performance of tourist function on the territory of Croatia, an analysis of changes in size of listed tourist indicators was carried out. Data for 1997 and 2017 were included in the study.

Analyzing the indicators describing tourist traffic, the first was Tourism Density Index calculated. It was calculated for the data for 1997 and it should be noted that only five of all counties match the assumed criteria of division. The highest value of the indicator was calculated for Istria County where it was 625.87. The second highest value was achieved in the city of Zagreb (in this region the criteria for Schneider's Rate weren't matched). In the case of Schneider's Rate the assumed criteria were matched in seven counties. The highest value of the indicator was calculated for Istria County where its value was 852.46.

By using the Rectangular Coordinate System method taking into account Tourism Density Index and Schneider's Rate the counties were divided into four groups (fig. 1). The first of them included counties matching the criteria for Schneider's Rate and not matching the criteria for Tourism Density Index. These are such county as: Lika-Senj, Zadar and Šibenik-Knin. The second group are counties in which the criteria for both indicators were matched: Istria, Primorje-Gorski Kotar, Dubrovnik-Neretva 
and Split-Dalmatia. Another group created counties for which the criteria for Tourism Density Index were matched but the criteria for Schneider's Rate weren't matched - city of Zagreb. The last group consists of counties in which the criteria for both indicators weren't matched. By analyzing the location of designated counties, it should be noted that they form two clusters in the north and in the south of the country. A buffer zone between the designated regions were formed by counties from the second group.

Data from 2017 was used in the next study (fig. 2). In the study conducted for Tourism Density Index eight counties met the set criteria, while the maximum value was reached in the City of Zagreb - 2005.34. In the case of Schneider's Rate criteria are met in ten regions. The highest value of the indicator was calculated for Istria County where it amounted to 1972.56. By using the Rectangular Coordinate System method taking into account Tourism Density Index and Schneider's Rate the counties were divided into four groups, one of them wasn't assigned any county. The first of the groups which included counties with matching the criteria for Schneider's Rate and those that didn't match the criteria for Tourism Density Index were two counties: Karlovac and Krapina-Zagorje. The next group with counties that match the criteria for both indicators has eight counties. These are all coastal counties and city of Zagreb. City of Zagreb due to its different character (completely urbanized area with a high intensity of tourist assets on a relatively small area) in relation to other counties matches the criteria. The third group consists of all the counties that don't match the criteria for the analyzed indicators.

The indicators describing the level of tourist development were analyzed and the values of BaretjeDefert's Index were calculated for the data from 1997 (fig. 3). Six countries were classified into the group of regions with a high level of tourism development. The maximum value of the indicator was calculated for Istria County and amounted to 105.98. In the case of Tourist Accommodation Density Index the adopted criteria allowed to classify seven counties as areas with a high level of tourist development. The highest value of the indicator was calculated for Istria County and amounted to 77.81 .

By using the Rectangular Coordinate System method taking into account Baretje-Defert's Index and Tourist Accommodation Density Index the counties were divided into four groups. The first of them included counties matching the criteria for Tourist Accommodation Density Index and not matching the criteria for Baretje-Defert's Index. This group includes two counties: Split-Dalmatia and the city of Zagreb. The second group consists of five counties

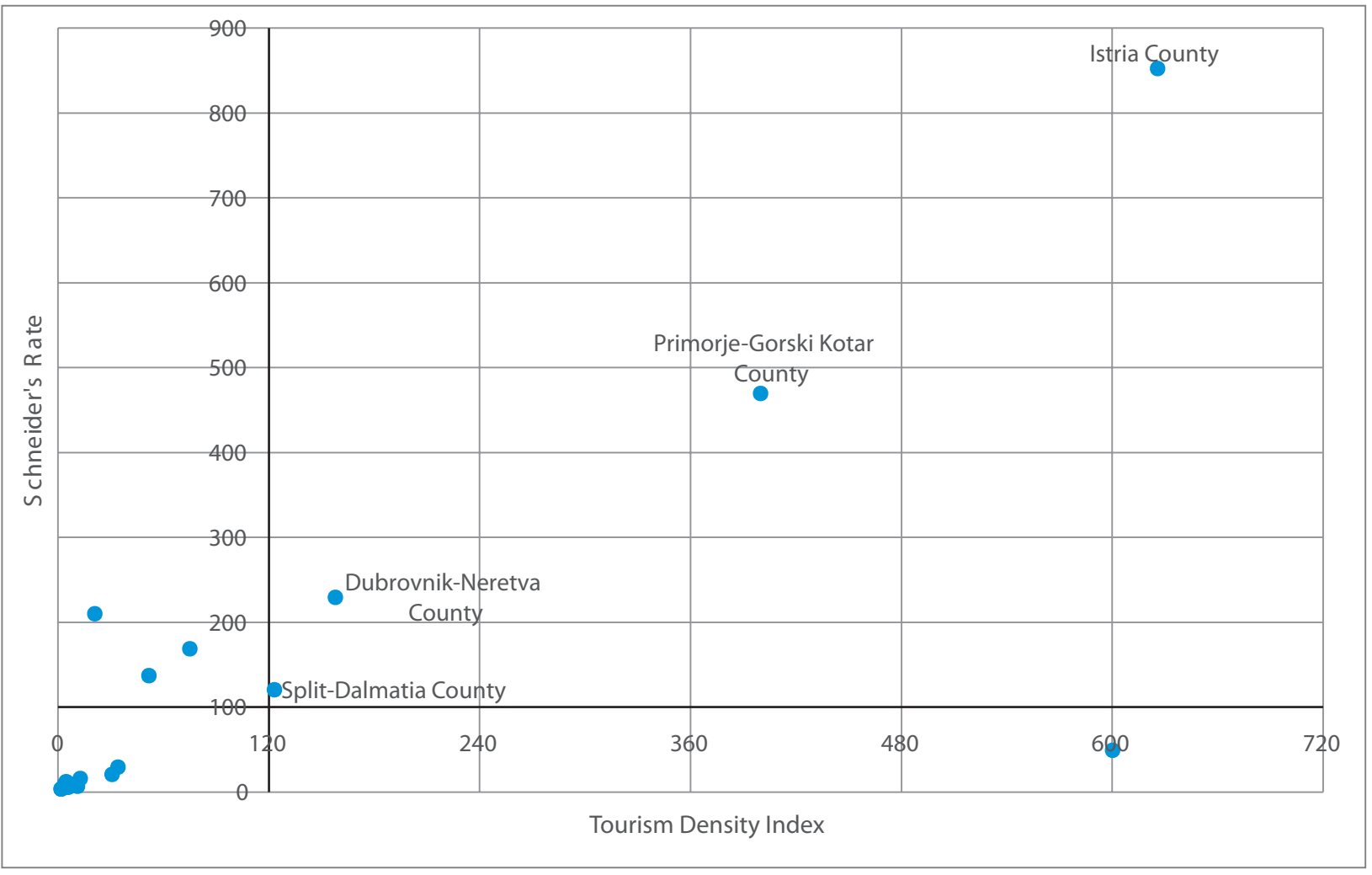

Fig. 1. Rectangular Coordinate System method for tourist traffic indicators in Croatia for 1997

Source: own elaboration based on Statistical Yearbook of the Republic of Croatia, 1997; Census of population, Households and Dwellings, 2003. 


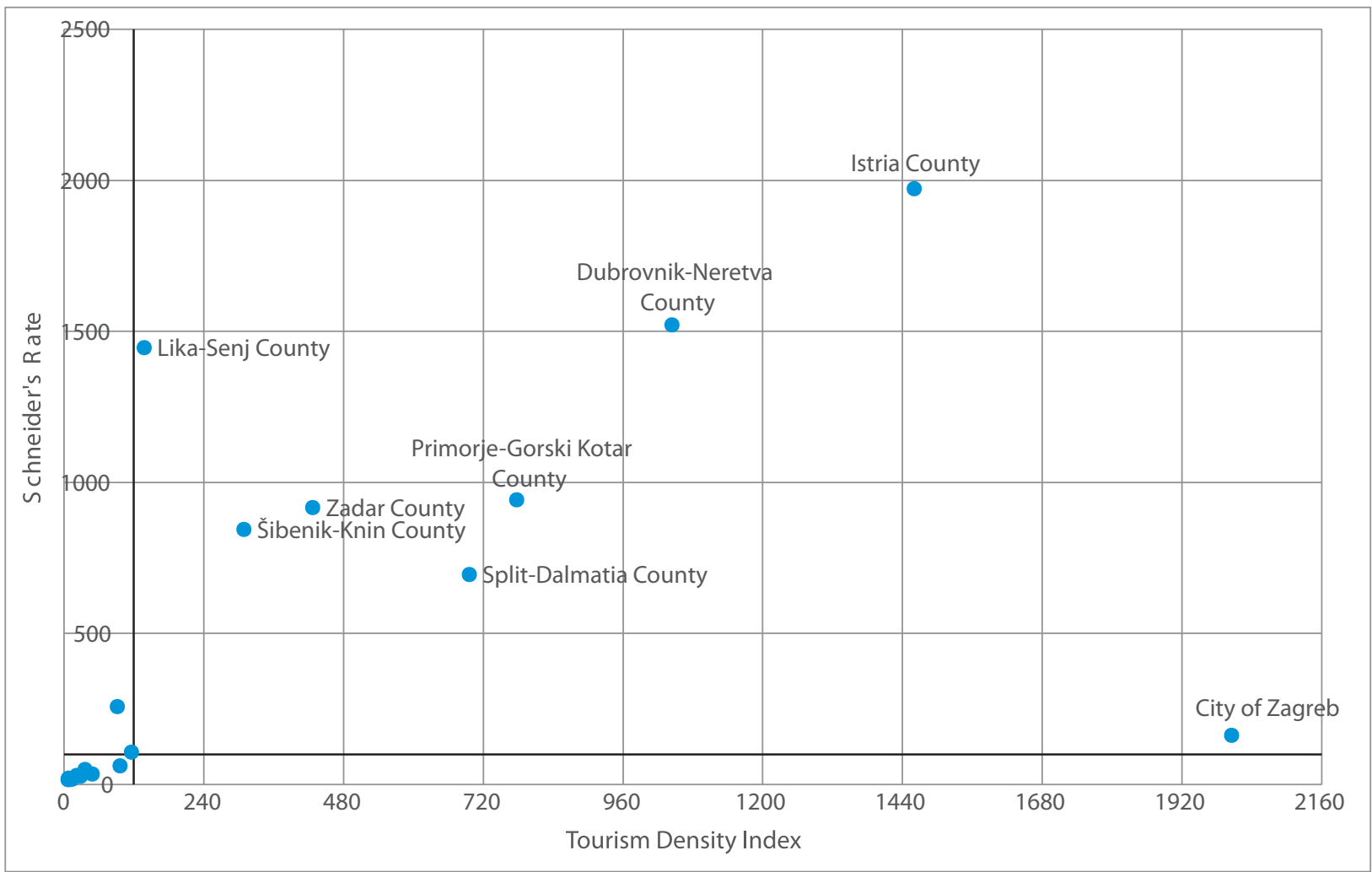

Fig. 2. Rectangular Coordinate System method for tourist traffic indicators in Croatia for 2017

Source: own elaboration based on Statistical Yearbook of the Republic of Croatia, 2017; Census of population, Households and Dwellings, 2013.

that match the criteria for both analyzed indicators. The next group creates counties in which a satisfactory level of Baretje-Defert's Index was achieved and the sufficiently high value of Tourist Accommodation Density Index wasn't achieved. Lika-Senj County is included in this group. The fourth group is made up of counties for which the values of both indicators haven't reached a satisfactory level.

Indicator values were calculated for data from 2017 (fig. 4.). In the case of Baretje-Defert's Index seven counties were classified as meeting the assumed criteria. The county with the highest value of the index was Istrian County for which the value of the index was 144.21. In the case of Tourist Accommodation Density Index the values for seven counties allowed them to be classified as high tourist development. The region with the highest index value was the Istrian county where its value was 106.76 .

By using the Rectangular Coordinate System method taking into account Baretje-Defert's Index and Tourist Accommodation Density Index the counties were divided into four groups. The first of them included counties matching the criteria for Tourist Accommodation Density Index and not matching the criteria for Baretje-Defert's Index. One of them was included in this group: the city of Zagreb. The second group includes 6 counties that match the criteria for both analyzed indicators. The next group creates counties in which a satisfactory level of Baretje-Defert's Index was achieved and the sufficiently high value of Tourist Accommodation Density Index wasn't achieved. Lika-Senj County is included to this group. The fourth group is made up of counties for which the values of both indicators haven't reached a satisfactory level.

To verify Rectangular Coordinate System, Perkal Synthetic Indicator was analyzed for six component indicators. These are indicators such as:

- Average Length of Stay;

- Accommodation Development Index;

- Tourism Density Index;

- Tourist Accommodation Density;

- Baretje-Defert's Index;

- Charvát Index.

The calculations are static in nature and relate to data for 1997 (table 1) and 2017 (table 2). Due to the value of Perkal Synthetic Indicator, counties were divided into groups. The arithmetic average () of differences in ordered values of Perkal Synthetic Indicator for individual counties was used to determine the boundaries between classes.

Four groups of counties were determined using the adopted criteria for data from 1997: 
Tab. 1. The value of Perkal Synthetic Indicator calculated for 1997

\begin{tabular}{|c|c|c|c|c|c|c|c|c|c|c|c|c|c|c|}
\hline \multirow[t]{2}{*}{ Country } & \multirow{2}{*}{$\begin{array}{l}\text { Average } \\
\text { Length of } \\
\text { Stay }\left(x_{1}\right)\end{array}$} & \multirow{2}{*}{$\begin{array}{c}\text { Accommodation } \\
\text { Development } \\
\text { Index }\left(\mathrm{x}_{2}\right)\end{array}$} & \multirow{2}{*}{\begin{tabular}{|c|} 
Tourism \\
Density \\
Index $\left(x_{3}\right)$
\end{tabular}} & \multirow{2}{*}{$\begin{array}{c}\text { Tourist } \\
\text { Accommo- } \\
\text { dation Den- } \\
\text { sity }\left(x_{4}\right)\end{array}$} & \multirow{2}{*}{$\begin{array}{l}\text { Baretje-De- } \\
\text { fert's Index } \\
\left(x_{5}\right)\end{array}$} & \multirow{2}{*}{$\begin{array}{c}\text { Charvát } \\
\text { Index }\left(x_{6}\right)\end{array}$} & \multicolumn{6}{|c|}{ Standardized values } & \multirow[t]{2}{*}{$\Sigma x_{i j}^{\prime}$} & \multirow[t]{2}{*}{$W_{s}$} \\
\hline & & & & & & & $\mathrm{x}_{1}^{\prime}$ & $x_{2}^{\prime}$ & $\mathrm{x}_{3}^{\prime}$ & $\mathrm{x}_{4}^{\prime}$ & $\mathrm{x}_{5}^{\prime}$ & $\mathrm{x}_{6}^{\prime}$ & & \\
\hline Istria & 6.99 & 8.04 & 625.87 & 77.81 & 105.98 & $5,961.35$ & 1.71 & -0.83 & 2.79 & 3.53 & 3.36 & 3.91 & 14.47 & 2.41 \\
\hline Primorje-Gorski Kotar & 5.71 & 9.61 & 399.88 & 41.60 & 48.86 & $2,680.18$ & 1.01 & -0.67 & 1.58 & 1.61 & 1.21 & 1.48 & 6.23 & 1.04 \\
\hline Dubrovnik-Neretva & 5.86 & 5.67 & 157.87 & 27.86 & 40.47 & $1,343.59$ & 1.10 & -1.06 & 0.29 & 0.89 & 0.90 & 0.50 & 2.60 & 0.43 \\
\hline City of Zagreb & 1.71 & 30.15 & 600.30 & 19.91 & 1.64 & 84.49 & -1.16 & 1.35 & 2.65 & 0.47 & -0.56 & -0.43 & 2.32 & 0.39 \\
\hline Zadar & 6.52 & 4.18 & 74.94 & 17.95 & 40.42 & $1,099.78$ & 1.45 & -1.21 & -0.15 & 0.36 & 0.90 & 0.32 & 1.66 & 0.28 \\
\hline Split-Dalmatia & 6.29 & 5.03 & 123.10 & 24.48 & 23.98 & 757.93 & 1.33 & -1.13 & 0.10 & 0.71 & 0.28 & 0.06 & 1.35 & 0.23 \\
\hline Šibenik-Knin & 6.51 & 3.77 & 51.88 & 13.77 & 36.46 & 893.31 & 1.45 & -1.25 & -0.28 & 0.14 & 0.75 & 0.16 & 0.97 & 0.16 \\
\hline Lika-Senj & 4.25 & 4.88 & 21.08 & 4.32 & 43.05 & 893.61 & 0.22 & -1.14 & -0.44 & -0.36 & 0.99 & 0.16 & -0.56 & -0.09 \\
\hline Vukovar-Srijem & 5.87 & 18.92 & 4.99 & 0.26 & 0.32 & 35.08 & 1.10 & 0.24 & -0.53 & -0.57 & -0.61 & -0.47 & -0.84 & -0.14 \\
\hline Krapina-Zagorje & 3.17 & 30.97 & 34.07 & 1.10 & 0.95 & 93.15 & -0.36 & 1.43 & -0.37 & -0.53 & -0.59 & -0.43 & -0.85 & -0.14 \\
\hline Osijek-Baranja & 2.81 & 34.61 & 12.59 & 0.36 & 0.46 & 44.40 & -0.56 & 1.79 & -0.49 & -0.57 & -0.61 & -0.46 & -0.90 & -0.15 \\
\hline Sisak-Moslavina & 3.56 & 30.72 & 3.90 & 0.13 & 0.31 & 33.43 & -0.15 & 1.41 & -0.53 & -0.58 & -0.61 & -0.47 & -0.94 & -0.16 \\
\hline Koprivnica-Križevci & 3.05 & 31.35 & 6.80 & 0.22 & 0.30 & 29.14 & -0.43 & 1.47 & -0.52 & -0.58 & -0.61 & -0.48 & -1.14 & -0.19 \\
\hline Varaždin & 3.23 & 19.33 & 30.90 & 1.60 & 1.09 & 68.22 & -0.33 & 0.28 & -0.39 & -0.50 & -0.58 & -0.45 & -1.97 & -0.33 \\
\hline Međimurje & 2.58 & 23.51 & 11.03 & 0.47 & 0.29 & 17.54 & -0.68 & 0.70 & -0.50 & -0.56 & -0.61 & -0.48 & -2.14 & -0.36 \\
\hline Zagreb County & 3.15 & 17.54 & 6.08 & 0.35 & 0.34 & 18.91 & -0.38 & 0.11 & -0.52 & -0.57 & -0.61 & -0.48 & -2.45 & -0.41 \\
\hline Brod-Posavina & 1.57 & 19.78 & 5.28 & 0.27 & 0.31 & 9.52 & -1.23 & 0.33 & -0.53 & -0.57 & -0.61 & -0.49 & -3.11 & -0.52 \\
\hline Virovitica-Podravina & 2.62 & 11.45 & 1.78 & 0.16 & 0.34 & 10.09 & -0.66 & -0.49 & -0.55 & -0.58 & -0.61 & -0.49 & -3.38 & -0.56 \\
\hline Požega-Slavonia & 1.79 & 14.66 & 1.79 & 0.12 & 0.26 & 6.80 & -1.12 & -0.18 & -0.55 & -0.58 & -0.61 & -0.49 & -3.52 & -0.59 \\
\hline Bjelovar-Bilogora & 1.70 & 13.79 & 3.31 & 0.24 & 0.48 & 11.17 & -1.16 & -0.26 & -0.54 & -0.58 & -0.60 & -0.49 & -3.63 & -0.60 \\
\hline Karlovac & 1.72 & 7.32 & 4.76 & 0.65 & 1.66 & 20.89 & -1.15 & -0.90 & -0.53 & -0.55 & -0.56 & -0.48 & -4.18 & -0.70 \\
\hline arithmetic average $(\bar{x})$ & 3.84 & 16.44 & 103.91 & 11.12 & 16.57 & 672.03 & & & & & & & & \\
\hline$S D$ & 1.84 & 10.14 & 187.29 & 18.89 & 26.63 & $1,353.12$ & & & & & & & & \\
\hline
\end{tabular}

Source: own elaboration based on Statistical Yearbook of the Republic of Croatia, 1997; Census of population, Households and Dwellings, 2003. 
Tab. 2. The value of Perkal Synthetic Indicator calculated for 2017

\begin{tabular}{|c|c|c|c|c|c|c|c|c|c|c|c|c|c|c|}
\hline \multirow[t]{2}{*}{ County } & \multirow{2}{*}{$\begin{array}{l}\text { Average } \\
\text { Length of } \\
\text { Stay }\left(x_{1}\right)\end{array}$} & \multirow{2}{*}{$\begin{array}{l}\text { Accommoda- } \\
\text { tion Develop- } \\
\text { ment Index }\left(\mathrm{x}_{2}\right)\end{array}$} & \multirow{2}{*}{$\begin{array}{c}\text { Tourism } \\
\text { Density } \\
\text { Index }\left(x_{3}\right)\end{array}$} & \multirow{2}{*}{$\begin{array}{c}\text { Tourist } \\
\text { Accommo- } \\
\text { dation } \\
\text { Density }\left(\mathrm{x}_{4}\right)\end{array}$} & \multirow{2}{*}{$\begin{array}{l}\text { Baretje- } \\
\text { Defert's } \\
\text { Index }\left(x_{5}\right)\end{array}$} & \multirow{2}{*}{$\begin{array}{l}\text { Charvát } \\
\text { Index }\left(\mathrm{x}_{6}\right)\end{array}$} & \multicolumn{6}{|c|}{ Standardized values } & \multirow[t]{2}{*}{$\Sigma x_{i j}^{\prime}$} & \multirow[t]{2}{*}{$W_{s}$} \\
\hline & & & & & & & $\mathrm{x}_{1}^{\prime}$ & $\mathrm{x}_{2}^{\prime}$ & $\mathrm{x}_{3}^{\prime}$ & $\mathrm{x}_{4}^{\prime}$ & $\mathrm{x}_{5}^{\prime}$ & $\mathrm{x}_{6}^{\prime}$ & & \\
\hline Istria & 6.20 & 13.68 & $1,460.25$ & 106.76 & 144.21 & $12,221.04$ & 1.94 & -0.94 & 2.06 & 3.11 & 2.63 & 3.16 & 11.95 & 1.99 \\
\hline Dubrovnik-Neretva & 4.14 & 20.52 & $1,044.29$ & 50.90 & 74.12 & $6,292.27$ & 0.63 & -0.54 & 1.29 & 1.13 & 1.01 & 1.30 & 4.83 & 0.81 \\
\hline Primorje-Gorski Kotar & 5.34 & 13.77 & 777,44 & 56.47 & 68.40 & $5,029.61$ & 1.40 & -0.93 & 0.79 & 1.33 & 0.88 & 0.91 & 4.38 & 0.73 \\
\hline City of Zagreb & 1.76 & 80.09 & $2,005.34$ & 25.04 & 2.03 & 286.55 & -0.88 & 2.96 & 3.07 & 0.22 & -0.65 & -0.57 & 4.15 & 0.69 \\
\hline Zadar & 5.91 & 9.72 & 427.31 & 43.98 & 94.40 & $5,422.10$ & 1.76 & -1.17 & 0.14 & 0.89 & 1.48 & 1.03 & 4.13 & 0.69 \\
\hline Split-Dalmatia & 5.25 & 11.99 & 695.76 & 58.03 & 57.95 & $3,649.03$ & 1.34 & -1.04 & 0.64 & 1.39 & 0.64 & 0.48 & 3.45 & 0.57 \\
\hline Šibenik-Knin & 5.91 & 9.49 & 308.98 & 32.54 & 88.90 & $4,987.69$ & 1.76 & -1.18 & -0.08 & 0.49 & 1.35 & 0.90 & 3.23 & 0.54 \\
\hline Lika-Senj & 3.60 & 16.65 & 137.60 & 8.26 & 86.83 & $5,197.68$ & 0.28 & -0.77 & -0.39 & -0.37 & 1.30 & 0.96 & 1.02 & 0.17 \\
\hline Krapina-Zagorje & 2.32 & 52.03 & 115.77 & 2.22 & 2.06 & 248.53 & -0.53 & 1.31 & -0.44 & -0.59 & -0.65 & -0.58 & -1.47 & -0.24 \\
\hline Međimurje & 2.39 & 45.73 & 96.48 & 2.11 & 1.35 & 147.75 & -0.48 & 0.94 & -0.47 & -0.59 & -0.67 & -0.61 & -1.88 & -0.31 \\
\hline Karlovac & 1.70 & 40.18 & 91.85 & 2.29 & 6.43 & 438.56 & -0.92 & 0.62 & -0.48 & -0.58 & -0.55 & -0.52 & -2.44 & -0.41 \\
\hline Vukovar-Srijem & 1.56 & 47.51 & 36.24 & 0.76 & 1.04 & 77.13 & -1.01 & 1.05 & -0.58 & -0.64 & -0.67 & -0.64 & -2.50 & -0.42 \\
\hline Zagreb County & 1.72 & 45.34 & 28.27 & 0.62 & 0.60 & 46.85 & -0.91 & 0.92 & -0.60 & -0.64 & -0.68 & -0.65 & -2.56 & -0.43 \\
\hline Bjelovar-Bilogora & 3.09 & 26.76 & 8.54 & 0.32 & 0.70 & 58.24 & -0.04 & -0.17 & -0.63 & -0.65 & -0.68 & -0.64 & -2.82 & -0.47 \\
\hline Sisak-Moslavina & 2.46 & 32.11 & 8.20 & 0.26 & 0.66 & 52.27 & -0.44 & 0.14 & -0.63 & -0.65 & -0.68 & -0.64 & -2.91 & -0.49 \\
\hline Osijek-Baranja & 1.93 & 36.73 & 22.20 & 0.60 & 0.82 & 58.25 & -0.78 & 0.41 & -0.61 & -0.64 & -0.68 & -0.64 & -2.94 & -0.49 \\
\hline Varaždin & 2.31 & 25.23 & 48.56 & 1.92 & 1.38 & 80.43 & -0.53 & -0.26 & -0.56 & -0.60 & -0.66 & -0.64 & -3.25 & -0.54 \\
\hline Koprivnica-Križevci & 2.09 & 27.42 & 10.60 & 0.39 & 0.58 & 33.58 & -0.67 & -0.13 & -0.63 & -0.65 & -0.68 & -0.65 & -3.42 & -0.57 \\
\hline Požega-Slavonia & 2.30 & 22.29 & 7.29 & 0.33 & 0.76 & 39.23 & -0.54 & -0.43 & -0.64 & -0.65 & -0.68 & -0.65 & -3.59 & -0.60 \\
\hline Virovitica-Podravina & 2.36 & 20.12 & 7.01 & 0.35 & 0.83 & 39.43 & -0.50 & -0.56 & -0.64 & -0.65 & -0.68 & -0.65 & -3.68 & -0.61 \\
\hline Brod-Posavina & 1.78 & 26.18 & 14.10 & 0.54 & 0.69 & 32.03 & -0.87 & -0.21 & -0.62 & -0.64 & -0.68 & -0.65 & -3.68 & -0.61 \\
\hline arithmetic average & 3.15 & 29.69 & 350.10 & 18.79 & 30.23 & $2,116.11$ & & & & & & & & \\
\hline SD & 1.57 & 17.04 & 538.63 & 28.31 & 43.40 & $3,201.21$ & & & & & & & & \\
\hline
\end{tabular}

Source: own elaboration based on Statistical Yearbook of the Republic of Croatia, 2017; Census of population, Households and Dwellings, 2013. 


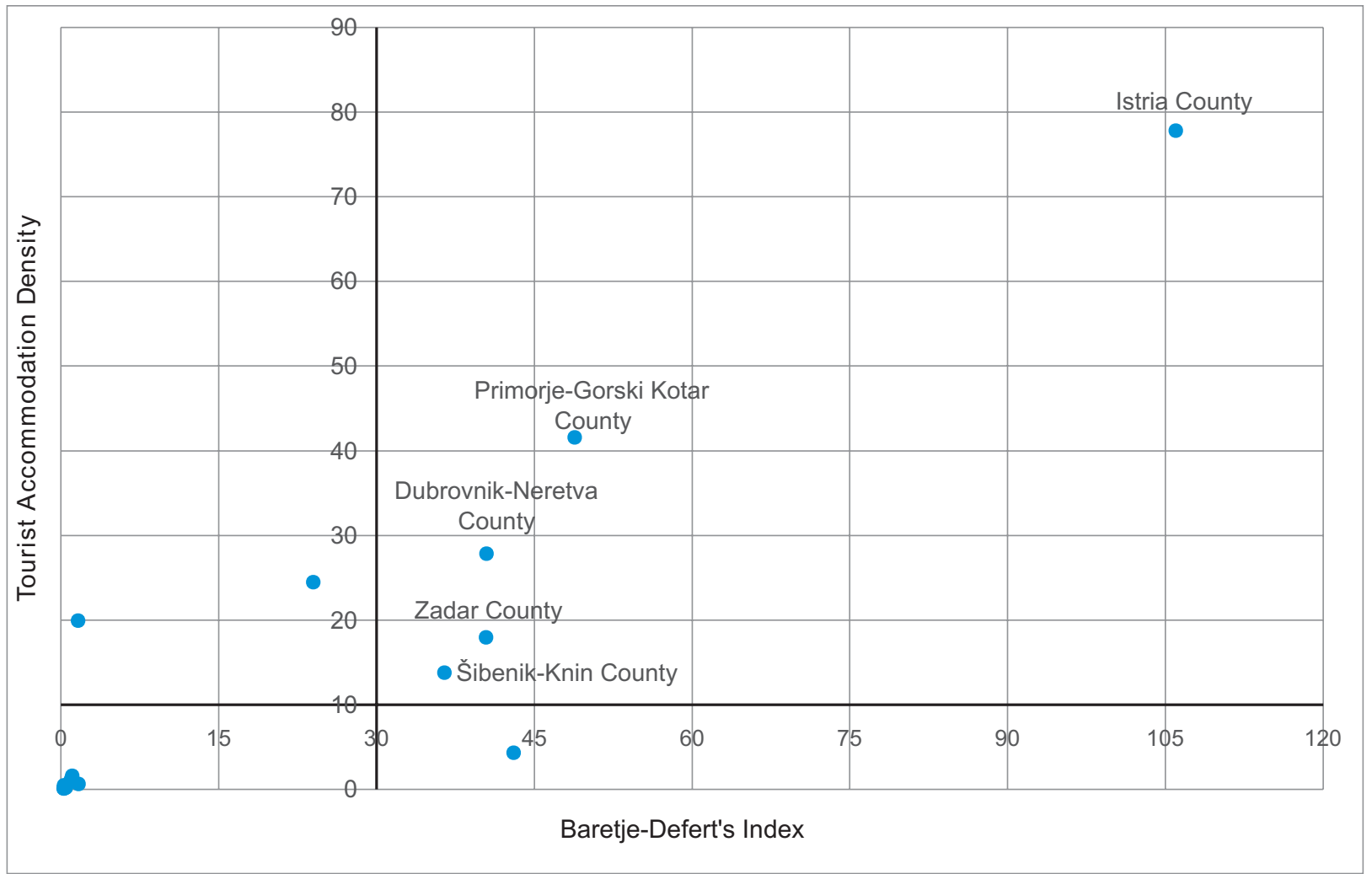

Fig. 3. Rectangular Coordinate System method for tourist development indicators in Croatia for 1997

Source: own elaboration based on Statistical Yearbook of the Republic of Croatia, 1997; Census of population, Households and Dwellings, 2003.

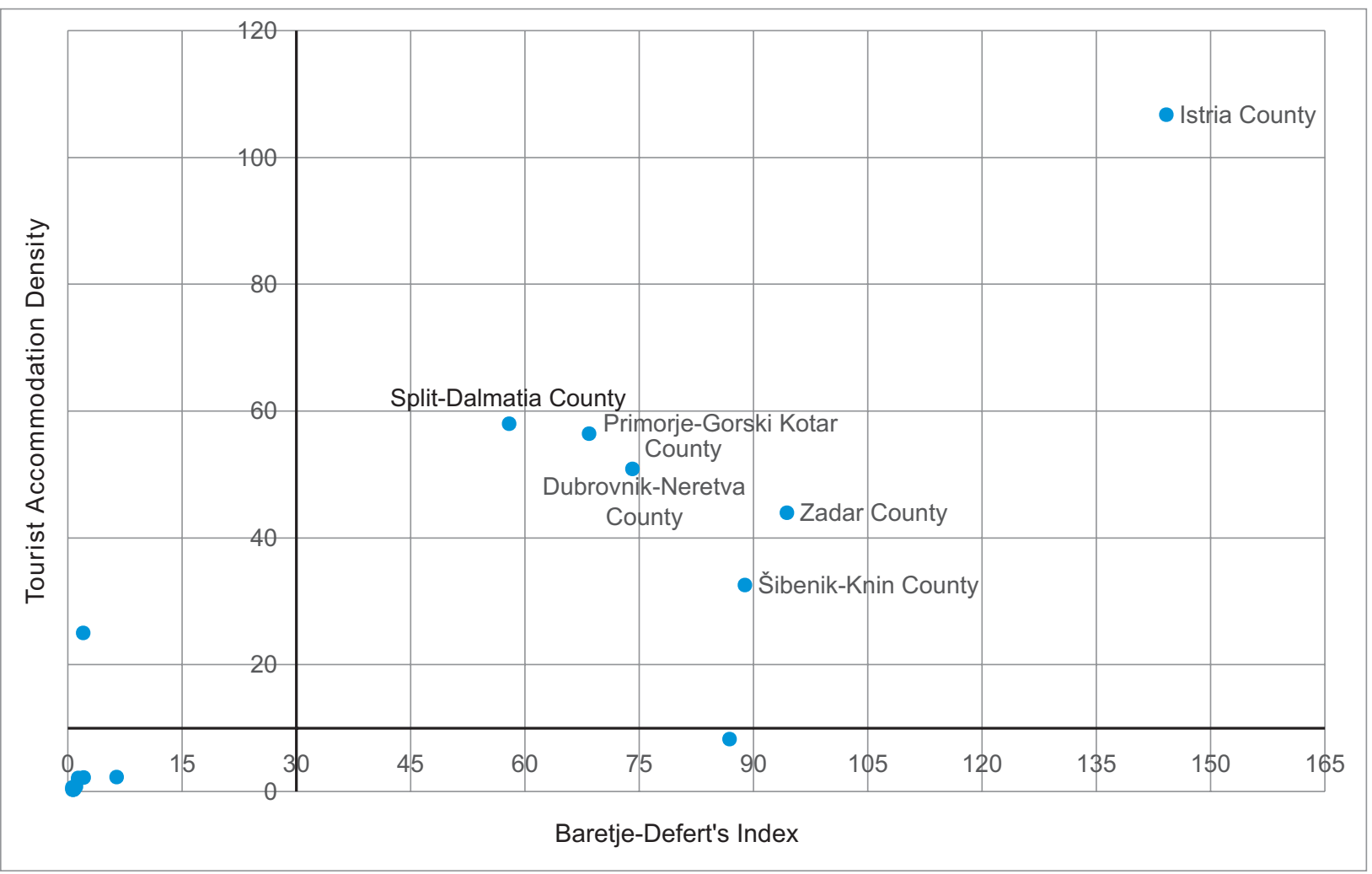

Fig. 4. Rectangular Coordinate System method for tourist development indicators in Croatia for 2017

Source: own elaboration based on Statistical Yearbook of the Republic of Croatia, 2017; Census of population, Households and Dwellings, 2013. 
- group I - county with the highest value of Perkal Synthetic Indicator, Istria County. It's located in the northern part of Croatia near the border with Slovenia. It influenced high value of standardized values;

- group II - Primorje-Gorski Kotar where the value of Perkal Synthetic Indicator is $\geq 1$;

- group III - contains 5 counties where the value of Perkal Synthetic Indicator is $\geq 0$. This group contains such counties as: Dubrovnik-Neretva, city of Zagreb, Zadar, Split-Dalmatia and Šibenik-Knin;

- group IV - counties with a negative Perkal Synthetic Indicator, i.e. Lika-Senj County and all inland counties excluding the capital of the country.

Three groups of counties were determined using the adopted criteria for data from 2017:

- group I - county with the highest value of Perkal Synthetic Indicator, Istria County. It's located in the northern part of Croatia near the border with Slovenia. It influenced the high value of standardized values;

- group II - contains 7 counties whose value of Perkal Synthetic Indicator is $\geq 0$. This group includes all other coastal counties and the capital of the country;

- group III - counties with a negative value of Perkal Synthetic Indicator, icludes all inland counties excluding the capital of the country.

\section{Conclusions}

Conducting the research procedure allowed to present basic changes in tourist flows and tourist development. The tourist function in Croatia was changed during analyzed 21 years. It can be concluded that there was a reduction in the number of counties groups by analyzing the Perkal Synthetic Indicator calculated for 1997 and 2017. On the other hand, there were even greater disparities in the tourist function between individual counties. What is important, in both cases it can be seen that in Istria County the tourist function is performed at the highest level compared to other counties of Croatia.

In terms of tourism flows, coastal areas have been combined into one group. The entire coastal area of Croatia can be classified as one tourist region. In addition, the capital of the country joined group of areas with increased use in terms of tourism. In Zagreb the volume of tourist flow increased more than threefold, in a similar way as in the whole country. The smallest increase in the number of tourists occurred in Koprivnica-Križevci County where the number of tourists increased by 0.5 times. The highest percentage increase in the number of tourists occurred in the Karlovac County where the number of tourists increased more than 19 times.

Such a big increase in the value of individual indicators has an impact on tourist carrying capacity and tourist absorption. The tourist season on the territory of Croatia starts in mid-June and lasts until mid-September when it begins to fade towards the south. Increased tourist traffic is also an increase in traffic on the roads which affects the formation of congestion. Despite the network of highways running through tourist regions, access to tourist destinations was difficult. Increased vehicle traffic combined with longtime travel from places generating traffic affect the safety of travelers and comfort of travel. Croatia's accession to the EU has reduced the waiting time at the border. This increased travel comfort. On the other hand this has led to an increase in the number of tourists so this problem remains relevant.

Performing the described study has its weaknesses. Use of the presented indicators related to tourism may raise doubts as to the correctness of their use. This raises the question of sufficient way of describing the phenomenon of tourism. Submission of data with 21 years of interval without an analysis of this period means that the study is incomplete and conclusions are limited.

\section{References}

Census of population, Households and Dwellings. 2011 edition, 2013, Croatian Bureau of Statistics, Zagreb.

Duro J.A., 2018, Seasonality of tourism: A new decomposition, Tourism Economics, 24(5), 615-621, doi: 10.1177/1354816618768319

Gogonea R.M., Baltalunga A.A., Nedelcu A., Dumitrescu D., 2017, Tourism Pressure at the Regional Level in the Context of Sustainable Development in Romania, Sustainability, 9(5), 1-24, doi: 10.3390/su9050698

Hacia E., 2014, The development of tourist space in Polish port cities, [in:] S. Ivan, R.G. Thompson (eds.), Procedia Social and Behavioral Sciences, 151, Elsevier Science BV, Amsterdam, 60-69.

Markovic S., Peric M., Mijatov M., Doljak D., Zolna M., 2017, Application of tourist function indicators in tourism development, Journal of the Geographical Institute "Jovan Cvijić" SASA, 67(2), 163-178, doi: 10.2298/IJGI1702163M

Matos Marquez L.A., Perez Colmenares S.D.V., 2019, Revision on tourist carrying capacity and the prevention of environmental problems in emerging destinations, Anuario Turismo y Sociedad, 24, 77-100, doi: 10.18601/01207555. n24.04

Muler Gonzalez V., Coromina L., Gali N., 2018, Overtourism: residents' perceptions of tourism impact as an indicator of resident social carrying capacity - case study of a Span- 
ish heritage town, Tourism Review, 73(3), 277-296, doi: 10.1108/TR-08-2017-0138

Narodne Novine, 10/1997, https://narodne-novine.nn.hr/ clanci/sluzbeni/1997_01_10_151.html (accessed 21 May 2019).

Pavia N., Floricic T., 2017, Innovative accommodation facilities in tourism and hospitality industry -integrated hotels, [in:] S. Markovic, D.S. Jurdana (eds.), Tourism in South East Europe, vol. 4., Faculty of Tourism and Hospitality Management, University of Rijeka, Rijeka, 437-450.

Podhorodecka K., Dudek A., 2019, Disadvantages Connected With the Development of Tourism in the Contemporary World and the Concept of Sustainable Tourism, Problemy Ekorozwoju / Problems of Sustainable Development, 14(2), 45-55.

Przybyla K., Kulczyk-Dynowska A., 2017, Transformations of Tourist Functions in Urban Areas of the Karkonosze Mountains, [in:] M. Drusa, I. Yilmaz, M. Marschalko, E. Coisson, J. Rybak, A. Segalini (eds.), IOP Conference Series-Materials Science and Engineering, 245, IOP Publishing LTD, Bristol, 1-7.

Rettinger R., 2010, Turystyka jako czynnik aktywizacji gospodarki Chorwacji (Eng. Tourism as an Incentive to Economic Growth in Croatia), Przedsiębiorczość-Edukacja / Entrepreneurship-Education, 6, 459-461.

Runge J., 2006, Metody badań w geografii społecznoekonomicznej - elementy metodologii, wybrane narzędzia badawcze (Eng. Research methods in socio-economic geography - elements of methodology, selected research tools), Wydawnictwo Uniwersytetu Śląskiego, Katowice.

Salo A., Garriga A., Rigall-Torrent R., Vila M., Fluvia M., 2014, Do implicit prices for hotels and second homes show differences in tourists' valuation for public attributes for each type of accommodation facility?, International Journal of Hospitality Management, 36, 120-129, doi: 10.1016/j. ijhm.2013.08.011

Scholz P., 2016, Applying elements of green management in accommodation facilities in Slovakia, [in:] S. Pachrova, M. Dolezalova (eds.), Aktualni Problemy Cestovniho Ruchu: "Mistni bohatstvi a cestovni ruch" (Eng. "Mistni bohatstvi a cestovni ruch". Local heritage and tourism), Vysoka skola polytechnicka Jihlava, Jihlava, 415-422.

Simancas Cruz M., Penarrubia Zaragoza M. P., 2019, Analysis of the Accommodation Density in Coastal Tourism Areas of Insular Destinations from the Perspective of Overtourism, Sustainability, 11(11), 1-19, doi: 10.3390/su11113031

Statistical Yearbook of the Republic of Croatia. 1997 edition, 1997, Croatian Bureau of Statistics, Zagreb.

Statistical Yearbook of the Republic of Croatia. 2017 edition, 2017, Croatian Bureau of Statistics, Zagreb.

Stefko R., Vasanicova P., Litavcova E., Jencova S., 2018, Tourism Intensity in the NUTS III Regions of Slovakia, Journal of Tourism and Services, 9(16), doi: 10.29036/jots.v9i16.43

Vojnovic N., 2018, Tourist intensity in Croatia's leading tourist towns and municipalities, Geoadria, 23(1), 29-50, doi: 10.15291/geoadria.1453

Wang Y., Xie T., Jie X., 2019, A mathematical analysis for the forecast research on tourism carrying capacity to promote the effective and sustainable development of tour- ism, Discrete and Continuous Dynamical Systems-Series S, 12(4-5), 837-847, doi: 10.3934/dcdss.2019056

Wiskulski T., 2019, Uwarunkowania ruchu turystycznego z Polski do Chorwacji (Eng. Conditions of Polish tourism flow to Croatia), Wydawnictwo AWFiS, Gdańsk.

Wiweka K., Arcana K.T.P., 2016, The Impact of Tourist Accommodation Development Toward The Socio-Cultural Aspects in The Seminyak Village, District of Kuta, Regency of Badung, Bali (in Perspective of the Local Community), [in:] A. M. Morrison, A. G. Abdullah, S. Leo (eds.), Asia Tourism Forum 2016 - The 12th Biennial Conference of Hospitality and Tourism Industry in Asia (ATF-16), series: Advances in Economics Business and Management Research, 19, 216-225. 